\title{
2000 年鳥取県西部地震の 10 年後の住宅再建支援の実態と住民意識からみた課題 \\ THE REALITY OF THE HOUSING RECONSTRUCTION SUPPORT 10 YEAR LATER OF 2000 WESTERN TOTTORI EARTHQUAKE AND THE PROBLEM JUDGED FROM RESIDENT CONSCIOUSNESS
}

\author{
浅井秀子*，熊谷昌彦** \\ Hideko ASAI and Masahiko KUMAGAI
}

\begin{abstract}
The problem to consider the overall victim of an accident support which is based on a case of western Tottori earthquake、 this research is having to do the exercise judged from the reality of the housing reconstruction support and resident's consciousness 10 years later Resident's endurance of the settlement consciousness、 population and number of households were maintained by doing housing reconstruction support. But it is difficult to say that housing as peculiar culture in an area was constructed. Therefore housing reconstruction support has to consider a rehabilitation plan including repairs and ways of construction、 to contribute to peculiar cultural maintenance and succession.
\end{abstract}

Keywords : Western Tottori Earthquake, Resident Consciousness, Public support for damaged private houses,

Tottori prefecture, Population decrease area

鳥取県西部地震，住民意識，個人住宅一の公的支援，鳥取県，人口減少地域

1. はじめに

\section{1 研究の背景}

日本は、地形や地質、気象などの自然的条件から、台風、豪雨、 豪雪、洪水、土砂災害、地震、津波、火山噴火などによる様々な災 害が発生しやすい国土となっている。このような現状を踏まえて、 自然災害による個人財産の被害について、「自助努力による回復」を 原則としていた国も 1995 年の兵庫県南部地震を契機に、1998 年に 「被災者生活再建支援法」(以後「支援法」と記載する) を制定した。 この制度では、全壊や居住不可能者の世帯に 100 万円を上限に支給 を定め、初めて被災者へ現金支給されることとなった。行政措置で 兵庫県南部地震の被災者も支給対象となり、一応の救済をみたが、 使途は洗濯機等の物品購入や移転費に限られ、住宅の建築費には使 えなかった。

被災者への生活再建支援策は、2004 年と 2007 年の改正が成され た。また自治体独自の補完制度によって、被災者は一応の救済をみ た ${ }^{1)}$ 。この法改正を経ても、半壊等の対象外世帯に対する支援や申 請手続きの簡素化とわかりや寸さ等の課題は残されたままであった。 2011 年に発生した東北地方太平洋沖地震は、人的被害（死者 16,079 人、行方不明者 3,499 人、負傷者 6,051 人）並びに物的被害 (全壊 120, 209 棟、半壊 189, 523 棟、一部破損 616, 217 棟、床上浸 水 10,971 棟、床下浸水 13,682 棟）ともに日本における最大規模を 記録した（2011 年 11 月 29 日消防庁緊急災害対策本部調）。この地
震は、巨大災害時に「支援法」を適用した初めての事例となった。 被災者の生活再建に関しては、「支援法」の本来の目的である「生活 基盤に著しい被害を受けたものであって経済的な理由等によって自 立して生活を再建することの支援」つまり個人の住まいの確保、生 活資金等の支給やその迅速な処理のための仕組みに加え、地域再生 につながるような総合的な被災者支援として、生業や就労の回復に よる生活資金の確保等生活全般についての支援方策についても検討 が必要となってきた。

\section{2 研究の目的}

本研究は、地域再生につながるような総合的な被災者支援のあり 方に関する検討に資するため、鳥取県が、地震の被災者支援に、全 国はじめてうちだした公的な住宅復興補助支援策を踏まえ、10 年後 の住宅再建支援の実態と住民意識からみた課題を明らかにすること を目的としている。被災者の生活再建過程は、初期と中長期の支援 があり、その過程において、初期の支援をいかに迅速に的確に行う かにより、再建の時間が短縮されると言われている ${ }^{2)}$ 。そのため本 研究では、被災住民の意識調査を踏まえて、初期の支援がその後の 地域への定住につながったことを明らかにする。

\section{3 既往研究と本研究の位置づけ}

本研究に関する既往研究として、いくつかの有益な研究が行われ ている。
$*$ 鳥取大学大学院工学研究科 准教授・博士 (工学)

** 米子工業高等専門学校建築学科 教授. 工博
Assoc. Prof., Graduate School of Engineering, Tottori University, Dr. Eng. Prof., Dept. of Architecture, Yonago National College of Technology, Dr. Eng. 
表 1 調査概要

\begin{tabular}{|c|c|c|c|c|c|c|c|c|}
\hline & 調査時期 & 調査対象 & 調査対象者 & $\begin{array}{c}\begin{array}{l}\text { 調査数 } \\
(\text { 戸) }\end{array} \\
\end{array}$ & $\begin{array}{l}\begin{array}{l}\text { 回収数 } \\
(戸)\end{array} \\
\end{array}$ & \begin{tabular}{|l} 
有効回答 \\
数 $($ 戸) \\
\end{tabular} & $\begin{array}{c}\begin{array}{l}\text { 回収率 } \\
(\%)\end{array} \\
\end{array}$ & 調査内容 \\
\hline 第1次調査 & 2000. 10. 7 2001. 2. 28 & & & & & & & $\begin{array}{l}\text { 官公庁資料により、被災や避難実態と鳥取県の公 } \\
\text { 的支援の特徵を把握した。 }\end{array}$ \\
\hline \multirow{3}{*}{ 第2次調査 } & 2001. 4. $20 \sim 4.28$ & 日野町S地区 & 全住戸 & 132 & 88 & 88 & 66.7 & \multirow{3}{*}{$\begin{array}{l}\text { 中山間地域の住宅の被災実態と生活再建過程を把 } \\
\text { 握した。 }\end{array}$} \\
\hline & $2001.5 .2 \sim 5.14$ & 日野町N地区 & 全住戸 & 307 & 154 & 154 & 50.2 & \\
\hline & $2001.5 .2 \sim 5.14$ & 日野町K地区 & 全住戸 & 248 & 109 & 109 & 44.0 & \\
\hline \multirow[b]{2}{*}{ 第3次調査 } & \multirow[b]{2}{*}{ 2010. 11. $20 \sim 12.24$} & 日野町S地区 & 全住戸 & 137 & 33 & 33 & 24.1 & \multirow[b]{2}{*}{ 公的支援の評価と課題を把握した。 } \\
\hline & & 日野町N地区 & 全住戸 & 308 & 135 & 135 & 43.8 & \\
\hline
\end{tabular}

従来の私有財産に対する公的補助の考え方の法的是非については、 阿部 $^{3)}$ が被災者への個人補償と行政施策の妥当性について、浦部 ${ }^{4}$ が公的支援と憲法について個人と公共とのとらえ方について、福崎 ${ }^{5)}$ が被災者救済のための理想的な法制度確立について言及している。 公的支援における鳥取県西部地震発生当時の国の見解については、 田近 ${ }^{6)}$ が「生活再建のための公的支援の課題とあり方」について、 国が「被災者の住宅再建支援の在り方に関する検討委員会報告書 ${ }^{7)} 」$ で報告している。公的支援についての議論が成された中で、佐藤 ${ }^{8)}$ が公的支援に対する経済学の視点から、大塚ら ${ }^{9)}$ が被災者生活再建 支援法や住宅再建支援をめぐる議論について言及している。

兵庫県南部地震後から住宅再建への公的支援の必要性については、 高田 ${ }^{10)}$ が住宅復興プロセスを軸に、室崎 ${ }^{11)}$ が災害復興の課題と方向 性、吉村 ${ }^{12)}$ が公助と共助の実態分析について言及している。

兵庫県南部地震後の被災者の移動とすまいの決定については、木 村 ${ }^{13)}$ が震災後における被災者の場所の移動パターンと寸まいの決 定の時期について考察している。

被災者の生活再建過程の時系列変化を追跡したものについては、 木村 ${ }^{14)}$ が兵庫県南部地震、新潟県中越地震、新潟県中越沖地震の3 つの災害における調查結果を比較し、生活再建過程の特殊性や一般 性について言及している。同じく木村ら ${ }^{15)}$ が、兵庫県南部地震の被 災者を対象に、生活再建過程における社会状況と被災者の意識や行 動パターンの関倸性について分析し、復興カレンダーの構築を行っ ている。その中で被災者の再建過程における行動は、10時間、100 時間、1000時間の3つの時間軸で区切られた4つのタイムフェーズで 変化するとしている。

一方鳥取県が、地震の被災者支援に、全国はじめてうちだした公 的な住宅復興補助支援策の評価については、大西 ${ }^{16)}$ が「住宅復興補 助金制度」を軸とした支援の実態と問題点を、基礎自治体・被災者・ 建築業者の 3 者の視点から把握している。そして村上ら ${ }^{17)}$ は、住宅被 害と復旧方法の関連から、住宅再建における補修と建替の選択につ いて言及している。

このような一連の研究はあるが、被災地において、自治体独自の 公的支援策について、住民の意識調查を踏まえて、時系列変化を追 跡した研究は少なく、その点においても他の研究と異なる。

\section{2. 研究の方法}

本研究の前提として、地震被災後の住宅再建支援は、行政による 支援と住民みずからが自立して再建しょうと寸る意識があいまって はじめて可能と考えている。高齢者が多い中山間地域では、都市で の再建方法と異なって、生活全般の再建にあたり定住意識を検討す ることに注目している。このような視点から、1998 年に創設された
「支援法」の直後に発生した 2000 年鳥取県西部地震における国の 制度運用とそれに伴う自治体独自の補完制度の課題を把握すること は、中山間地域の再建支援策を検討寸る上で、重要であると考えて いる。

したがって、はじめに住宅再建支援に対する行政の対応、次に公 的支援に対する意識を含めた各地域の住民意識の順に構成している。 そのため研究の方法として、(1) 鳥取県西部地震の被災実態 ${ }^{18,19,20) 、 ~}$

（2）1998 年に創設された「支援法」の変遷経緯を踏まえて、住宅再 建支援に係る改正箇所を把握、(3)国の支援制度を補完している制度 については、鳥取県では全国で初めて自治体独自に打ち出した「鳥 取県西部地震被災者向け住宅復興補助事業 ${ }^{19}$, 20) 」とその後に制定し た「鳥取県被災者生活再建支援制度 ${ }^{19}$ 、20)」、(4) それらの補完制度の 必要性を示す資料として補助金及び支援金の執行状況の資料、その 評価と課題を把握するため、(5) 地震直後と 15 年後の家屋状況の変 化を罹災判定結果ごとに比較する注 1)、(6) 公的支援のあり方につい て、鳥取県内の被災を受けた直後 ${ }^{21,22)}$ と 10 年後の日野町の住民の 意識調査、（7）地震直後の人口変動から、自治体独自の住宅再建支援 策への評価を把握する(表 1)。最後にその取り組みから、現行の法 改正後の課題と中山間地域における課題の検討を行う。それらは、 地震災害復興計画上の公的支援の意味と課題につらなっている。

\section{3. 地震の概要 $\left.{ }^{19} 、 20\right)$}

鳥取県西部地震は、2000 年 10 月 6 日 13 時 30 分頃、鳥取県西部 (北 緯 35.3 度、東経 133.4 度) で、震源の深さ $10 \mathrm{~km}$ 、マグニチュード 7.3 が起こった。鳥取県注 2)では、境港市と日野町注 ${ }^{3)}$ が震度 6 強で あった(図 1)。そのうち米子市・境港市・日野町・西伯町・会見町・ 溝口町が災害救助法適用に該当した。他方島根県では、安来市と伯 太町が災害適用救助法に該当した。また同規模の地震の被災の程度 に比べると建物被害や人的被害が小さかったことから、その原因に ついて様々に議論されている ${ }^{18)}$ 。地元では、地震時が昼食後の午後 1 時 30 分頃であり、地震時の火災による被災がほとんどなかったこ とや、さらに構造の専門家の意見では、民家の頑丈さが、木造建築 の被災を少ないものにした原因の一つとして挙げている ${ }^{23)}$ 。他方、 鳥取県の事前の関連機関との協定の締結、事前の防災訓練と迅速な 応急対応等の理由も挙げられる ${ }^{24)}$ 。また地域住民の結びつきの強さ や鳥取県の迅速な住宅再建の補助制度を挙げてもいる。

地震における人的被害は、重傷者 31 人、軽症者 110 人の計 141 人であった。鳥取県内の被災状況としては、住家被害は、全壊 391 棟・半壊 2, 472 棟・一部損壊 13,195 棟であった。最も大きな震度が 記録された日野町の住家被害は、全壊 129 件・半壊 441 件・一部破 損 945 件で合計 1,515 件であった。直接地震の摇れにより損壊した 


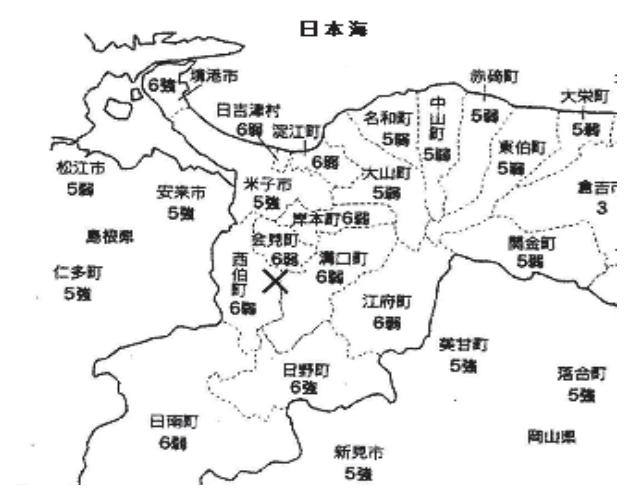

図1 鳥取県西部地震被災状況 ${ }^{18}$ ( $x$ 印：震央位置)

ものの他、地盤の液状化により地盤沈下、傾斜等したものもあった。

\section{4.「支援法」の変遷経緯と改正箇所}

1998 年に創設された「支援法」の変遷経緯と住宅再建支援に係る 部分の改正䇢所について以下に示す。

1999 年の法改正は、国の省庁組織の名称変更による改正であって、 法律条文の改正は行われていない(表 2)。2004 年の改正で、「居住安 定支援制度」が追加され、住宅の再建・補修に 200 万円を上限に支 給することが決定した。大規模半壊世帯も支援対象となり拡充が図 られた。但し住宅の建築費には使えないこと等、国の姿勢は変わら なかった。そのため 1995 年の兵庫県南部地震を教訓に共済制度づく り注 4)を進める兵庫県をはじめ、自治体が独自の支援策の実施注 5) 等 を検討する動きも広がっている。2007 年の改正は、住宅再建の形に 応じて、最大 300 万円を定額方式で支給し、使用目的を限定なしと し、支給対象の年齢や年収要件を撤廃した。さらに特例措置として 能登半島地震、新潟県中越沖地震、台風 $11 \cdot 12$ 号の被災者に限り、 改正後の制度を利用可能とした。但し、半壊世帯は対象外とされた。

\section{5. 住宅への支援活動 ${ }^{19 、 20)}$}

鳥取県は、独自の個人住宅への公的支援を 10 月 17 日という地震 後 11 日目にうちだし、地域復興への基礎をつくった。鳥取県は、鳥 取県西部地震の被災者支援策として、全国的にはじめて公的な住宅 復興補助制度をうちだした。

従来、住宅を失った被災者に対する公的支援は、被災直後の仮設 住宅や復興後の復興公営住宅等に限られていた。同制度は、鳥取県 西部で被害を受けた個人住宅の建て替えや補修に助成する市町村に 対し、県が補助する制度であり、住宅再建は、居住していた市町村 内に限っている。その内容は、全国的に注目されている「住宅復興 補助金の交付」をはじめ 9 つある(表 3 )。全壊・半壞の区別なく、 建替の場合は 300 万円、補修と石垣・擁壁補修の場合は 150 万円を 限度に、補助金の交付を行なうものであった (表 4)。県負担以外の 市町村と本人の負担割合は、事業主体の市町村に委礼らていた。 全半壊戸数が全町の約 $1 / 3$ に上った日野町では、補修についても県 費負担以外を全て日野町が肩代わりする方針を打ち出したが、大半 の市町村は、補修費については本人負担を求める方針とした。その 結果、補修の最高補助額は日野町の 150 万円に対して、負担割合に 応じて、116 万 6 千円から 96 万 6 千円 (高齢者世帯は除く)まで地域
差が生じた。また米子市、境港市や西伯町などは、10 万円以下は補 助対象にしない下限を設けた。災害廃棄物処理事業(解体処理業務) は、日野町に限り鳥取県が半額負担を行った。これらの支援策は、 住民にとっては必要なことであったが、日野町にとっては、復興事 業予算額に対して町肩代り負担額が約 $1 / 6$ を占める等、町財政を圧 迫する結果となった(表 5)。2001 年に、住宅再建に最高 300 万円を 支給する「住宅再建支援条例」が鳥取県議会で採択された。また財 源確保のため鳥取県と県内市町村が出資する「鳥取県住宅再建支援 基金」を創設した。県と市町村で年 1 億円ずつ拠出し、25 年で 50 億円を積み立てることとした。これに呼応する動きは他県に必ずし も波及していない。しかし鳥取県の動きは、兵庫県南部地震以降の 住宅再建をめぐる議論に一石を投じていると考える ${ }^{7)}$ 。補助金の執 行状況からは、建替世帯よりもむしろ補修への対応が手厚かったこ とは、一部損壊を含む軽微な損壊への支援を行うことにつながり、 生活再建への一助となった(図 7)。なお、液状化被害への補助は 11 月 24 日にうちだしている。

\section{6. 日野町における被災直後 (2001年) と2015年の家屋状況の変化}

日野町 N 地区・K 地区・S 地区の被災直後 (2001 年) と 2015 年との 家屋状況の変化を罹災判定結果ごとに比較する(表 6、図 2)。全壊判 定の家屋は、2000 年から 2010 年の間、いずれの地区でも約半数が

「建直し」を行っているが、2010 年以降は、全く「建直し」も行っ ておらず、「空地」にもなっていない。半壊判定の家屋は、2000 年 から 2010 年の間、いずれの地区でも約 1 割が「建直し」を行うか、 もしくは「空地」になっている。2010 年以降は、数件であるが、「建 直し」を行っている。一部破損判定の家屋は、2000 年から 2010 年 の間、 $N$ 地区は約 1 割、K 地区は約 0.5 割が「建直し」行うか、もし くは「空地」になっているが、S 地区では変化なしである。2010 年 以降は、全く「建直し」も行っておらず、「空地」にもなっていない。

以上のことより、2000 年から 2010 年の間の被災地の地区におけ る家屋状況の変化 (表 6) は、「建直し」はみられるものの、「空地」 は、全壞、半壞、一部破損あわせて 18 件である。2010 年以降の「建 直し」は、半壊判定の家屋では 3 件のみで、いずれの地区でも「空 地」にはなっていない。それらのことより、家屋の解体・撤去を防 ぐことができたと考える。また人口・世帯状況の変化(表 7) からみ て、いずれの地区においても、自然減と予想される人口減はみられ るものの世帯数の大幅な減少はない。

\section{7. 日野町における被災住民の定住意識}

本章では、被災住民の震災直後と 10 年後の住宅再建に関する定住 意識を分析するため2次調查と 3 次調査を比較する。

\section{1 約半年後の住民定住意識21）（2001年調査）}

回答者年代は、「70 代以上」が、各地区共に 4 割を占める (図 3)。 世帯主の職業は、「年金受給者」が、各地区共に 4 割弱、「会社員」 が、各地区共に 3 割弱である。また N 地区と K 地区で「自営業」が みられる(図 4)。同居人数は、各地区共に、単身高齢者及び高齢者 世帯をあわせると 5 割を占める (図 5)。居住年数は、各地区共に、

「代々住んでいる」「20 年以上」とあわせると 9 割程度を占め、地 域に定着した住民であることがわかる(図 6)。罹災判定結果は、S 地区で、「全壊」と「半壊」をあわせると 8 割を占めるが、各地区 
表 22000 年被災者生活再建支援制度 (国)

\begin{tabular}{|c|c|c|c|c|c|}
\hline \multicolumn{6}{|c|}{ 0年被災者生活再建支援制度(国制度)，改正: 平成11(1 } \\
\hline 1.対象自然災害 & \multicolumn{5}{|c|}{ 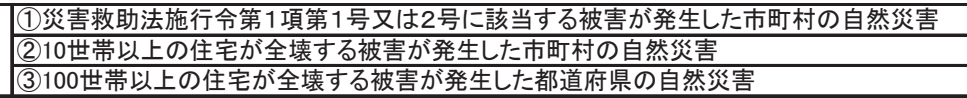 } \\
\hline & \multicolumn{5}{|c|}{$\begin{array}{l}\text { 全壊世帯、これと同等の被害を受けたた世帯 } \\
\text { 半壊世帯で、倒壊防止·補修費用が著しく高額等の事由で解体又は解体された世帯 } \\
\text { 火砕流等の被害の継続等の事由で居住不能つその状態が長期継続が見込まれる世帯 }\end{array}$} \\
\hline \multirow{7}{*}{$\begin{array}{c}\text { 3.補助対象基準額(単 } \\
\text { 位:千干円) }\end{array}$} & 世帯の収入、基準等 & 世帯 & 支援対象経費 & 全壊 & 半壊世帯 \\
\hline & \multirow[t]{2}{*}{ 世帯全体の収入が500万円以下の場合 } & 複数 & \multirow{2}{*}{ 区分なし } & 1,000 & 1,000 \\
\hline & & 単数 & & 750 & \\
\hline & \multirow{2}{*}{ 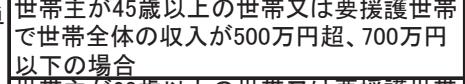 } & 複数 & \multirow{2}{*}{ 区分なし } & 500 & 500 \\
\hline & & 単数 & & 375 & 375 \\
\hline & \multirow{2}{*}{$\begin{array}{l}\text { 世帯主が60歳以上の世帯又は要援護世帯 } \\
\text { で世帯全体の収入が700万円超, } 800 \text { 万 } \\
\text { 以下の場合 }\end{array}$} & 複数 & \multirow{2}{*}{ 区分なし } & 500 & 500 \\
\hline & & 単数 & & 375 & 375 \\
\hline
\end{tabular}

*使用目的は、生活必需品等の購入のための経費とする

表3 鳥取県の住宅支援策 ${ }^{19}$ 、20)（件数及び鳥取県補助額は2006年3月末日現在 住宅政策課調）

\begin{tabular}{|c|c|c|c|c|c|}
\hline (担当課) & 事業内容 & \multicolumn{2}{|c|}{ 件数 } & 金額（千円） & 備 \\
\hline \multirow{5}{*}{ 1、住宅復興補助金の交付 (住宅環境課) } & \multirow{5}{*}{ 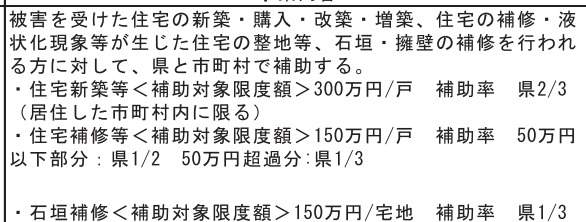 } & \multicolumn{2}{|c|}{ 適用期間（申請）：建設 } & H12 H14.10.5 & , 補修等 H12 H13.10.5 \\
\hline & & 住宅建設 & 520 & $1,039,727$ & 完了：H16.3.31 \\
\hline & & 住宅補修 & 11,933 & $4,097,827$ & 完了：H15.3.31 \\
\hline & & 液状化建物復旧 & 259 & 131,019 & 完了:H14.10.31 \\
\hline & & 石垣等補修 & 1,124 & 332,718 & 完了：H14.10.31 \\
\hline $\begin{array}{l}\text { 2、災害復興住宅资金（住宅金融公庫等）の } \\
\text { 利子補給(住宅環境課) }\end{array}$ & 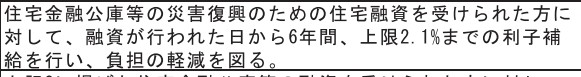 & \multicolumn{2}{|c|}{ *延 5,480} & 448,648 & 適用期間(申請)：H12 H15.3.31 \\
\hline \multirow[t]{2}{*}{$\begin{array}{l}\text { 3、災害復興住宅建設資金（県の上乗せ融 } \\
\text { 資）の貨付及び利子補給 (住宅環境課) }\end{array}$} & 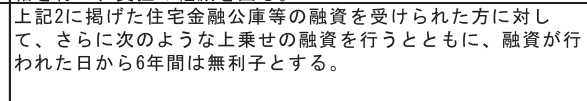 & 貸付 & 17 & $\begin{array}{r}{[61,500]} \\
28,290\end{array}$ & $\begin{array}{l}\text { 適用期間(申請)：H12 H15.3.31、上 } \\
\text { 段］書きは貸付金額 } \\
\text { 貸付残高の } 46 \% \text { 県が預託 }\end{array}$ \\
\hline & $\begin{array}{l}\text { <融資金額>建設400万円（20年償還・据置なし）補修 } 200 \text { 万 } \\
\text { (10年㯽遠・据なし) }\end{array}$ & 利子補給 & * 延70 & 4,148 & \\
\hline 4、民間賃貸住宅への家貨補助(住宅環境課) & 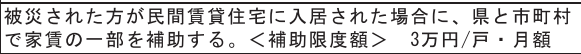 & & 70 & 3,810 & $\begin{array}{l}\text { 適用期間 (申請) : H H12 H13.12. 末) 米 } \\
\text { 子市62件、西伯町7件、日吉津村1件 }\end{array}$ \\
\hline $\begin{array}{l}\text { 5、民間借上げ空き家への家貨補助（住宅環境 } \\
\text { 課） }\end{array}$ & $\begin{array}{l}\text { 市町村が借り上げた民間空き家に、被災された方が入居された } \\
\text { 場合に、、県と市町村で家貢の一部を補助する。く補助限度額 }> \\
\text { 3万円/戸・額 }\end{array}$ & & 10 & 855 & \begin{tabular}{|l} 
適用期間 (申請)：H12 H13. 12. 末) \\
西伯町10件
\end{tabular} \\
\hline 6、災害援護資金の貸付 & 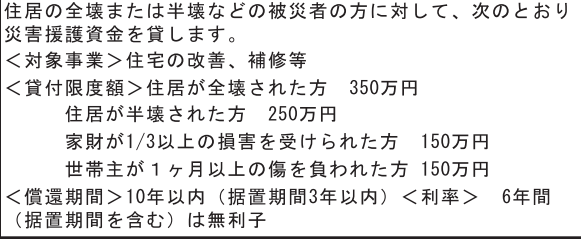 & \multicolumn{2}{|r|}{6} & 163,931 & (注：件数は市町村数) \\
\hline $\begin{array}{l}\text { 7、生活福祉資金の中の災害援護資金・住宅 } \\
\text { 資金の貨付(福祉健康課) }\end{array}$ & 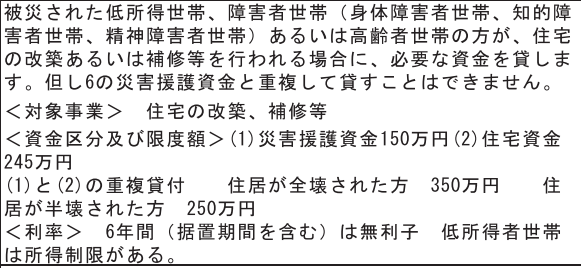 & \multirow{2}{*}{\multicolumn{2}{|c|}{16}} & 45,929 & （注：件数は世帯数） \\
\hline 8、母子寡婦福祉資金の貸付（子育て支援課） & 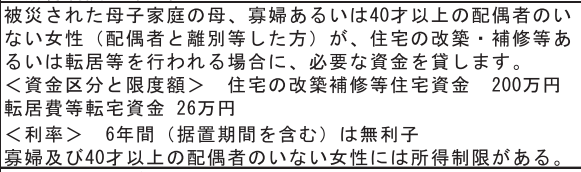 & & & 9,060 & (注 : 件数は世带数) \\
\hline 9、県営住宅の家貨免除 (住宅課) & 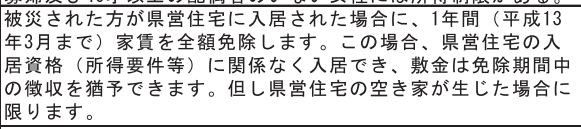 & & 38 & 6,198 & $\begin{array}{l}\text { 期間 : 入居から } 1 \text { 年間、対象者: 罹災 } \\
\text { 証明の交付を受けたた者、減免期間 : 平 } \\
\text { 成13年9月末まで }\end{array}$ \\
\hline 被災者向け公棠住宅建設等事業（県嵩上げ） & 西伯町落合団地 14戸， 日野町野田団地 4 戸, 日野町第2黒坂 & & 26 & 92,029 & 適用期間 : H 13 年度着工分 \\
\hline 被災者向け仮設住宅建設等事業 & 日野町野田団地 4戸，安原団地 2戸，下榎団地 6戸，黒坂 & & 28 & 119,389 & 適用期間：H12 H14.11.10 \\
\hline 被災家屋等解体支援事業（循環型社会推進課） & 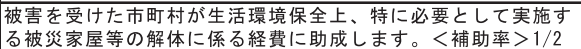 & - & & - & 件数等は不明 \\
\hline
\end{tabular}

各内の担当浬は积受けているものを重複してカウントしている。

表 4 鳥取県被災者生活再建支援制度 $19 、 20)$

被災者生活再建支援制度(鳥取県制度), 創設: 平成13(2001)年7月6日

\begin{tabular}{|c|c|c|c|c|c|}
\hline \multicolumn{6}{|c|}{ 被災者生活再建支援制度(鳥取県制度)，創設: 平成13(2001)年7月6日 } \\
\hline 1.対象自然災害 & \multicolumn{5}{|c|}{ 鳥取県内で10戸以上の住宅が全壊する等、地域の崩壊を招くような自然災害 } \\
\hline 2.対象世帯 & \multicolumn{5}{|l|}{ 被災程度条件なし } \\
\hline \multirow{2}{*}{$\begin{array}{c}\text { 3.補助対象基準額(単 } \\
\text { 位: 千円) }\end{array}$} & 世帯の収入、基準等 & 世帯 & 支援対象経量 & 新築·購入 & 補修 \\
\hline & 所得制限·年齢制限なし & 区分なし & 区分なし & 3,000 & 1,500 \\
\hline
\end{tabular}


共に、ほとんどの住宅に被害がみられる（表6）。震災後の生活へ の影響は、「生活への影響はそれほじでもない」が、S地区29.1\%、 N地区69.5\%、K地区64.2\%である。しかし「家計が苦しい」が、S 地区 $34.9 \%$ 、「大幅な収入減」が、S地区 $14.0 \%$ 、「営業不振」が、 N地区9.7\%等、経済的不安もみられる(表8)。今後の予定は、「住 み続けたい」「出来れば住み続けたい」とあわせると、各地区共 に9割を占める(表9)。その理由は、「親の代から住んでいるから」 が、S地区 $64.0 \%$ 、N地区 $53.2 \%$ 、 K地区 $56.9 \%$ 、「近くに知人・友人 がいるから」が、S地区17.4\%、N地区31.8\%、K地区32.1\%である(表 10)。被災住宅の再建方法は、「補修あるいは補強して住む」が、 S地区69.9\%、N地区65.0\%、K地区69.2\%である(表11)。高齢者の多 い地域では、住宅再建を希望する場合、建替えは困難であるため、 「補修、補強して住む」との回答が7割程度を占める。

以上のことより、住宅復興補助金の導入は、特に被苂が軽微な 世帯にとって一助となっていて、そのことが被災住宅の再建方法 においても、各地区で、「補修あるいは補強して住む」が約 7 割 を占める結果につながっている。しかし経済的不安も抱えており、 土地を離れることなく住み続けたいとの意向は、住宅再建のため の資金やローン返済等の不確定要素を含んでいた (表 8)。一方で 生活再建に関わる支援制度が利用されない状況も指摘されている 16)

\subsection{0 年後の住民定住意識 (2010年調査)}

回答者年代は、「70 代以上」が、各地区共に 5 割を占める (図 3)。世帯主の職業は、「年金受給者」が、各地区共に 4 割弱、「会 社員」が、震災直後より減少傾向にある。また $N$ 地区と K 地区で 「無職」が目立つ等、震災直後と比較して職業の変化がみられる (図 4)。同居人数は、各地区共に、単身高齢者及び高齢者世帯を あわせると 5 割で、震災直後から変化はみられない(図 5)。居住 年数は、各地区共に、「代々住んでいる」「20 年以上」とあわせ ると 9 割程度を占め、震災直後から変化はみられない(図 6)。罹 災判定結果は、S 地区では、「全壊」と「半壞」をあわせて 8 割 を占める等の地区の相違はあるが、各地区共に、ほとんどの住宅
に被害がみられる(表 6)。

公的支援の受給有無は、「受けた」が、S地区97.0\%、N地区79.3\%、 K 地区 $82.1 \%$ 、 8 割以上が公的支援を受けていることがわかる。 公的支援の必要性は、「必要だった」「やや必要だった」とあわせ ると、各地区共に 9 割を占める(表 12)。「必要だった」と回答し た理由は、「修理に必要」「自己再建資金不足」「公的支援のおかげ で、住み続けることができた」「人口の流出を防ぐために必要だっ た」等である。公的支援の決定時期は、「適当だった」が、S 地区 $81.8 \%$ 、 地区 $85.2 \%$ 、 K 地区 $85.7 \%$ で、8 割程度を占める(表 13 )。 「適当だった」と回答した理由は、「安心できた」「早期決断で元 気が出た」「余震と心の泠静さを取り戻した頃で適切に受け止めら れた」「頑張万うという気になれた」「早ければ早い方がよい」等 である。公的支援の支給基準は、「適正だった」「やや適正だった」 とあわせると、各地区共に 5 割を占める(表 14)。公的支援の満足 度は、「満足」が、S 地区 $30.3 \% 、 N$ 地区 $37.8 \%$ 、K 地区 $42.9 \%$ 、「や

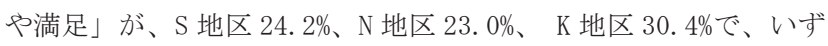
れの地区でも「満足」「やや満足」とあわせて 6 割程度を占める (表 15）。公的支援の課題は、「被災判定の基準」が、S 地区 48.5\%、N 地区 $29.6 \%$ 、K 地区 $32.1 \%$ で突出している(表 16)。有効な生活支援 策は、S 地区では、「給水」78.8\%、「ビニールシートの配布」69.7\%、

「住宅再建支援制度」 $66.7 \%$ 、N 地区では、「ビニールシートの配 布」43.0\%、「住宅再建支援制度」39.3\%、「罹災証明書の発行」30.4\%、 K 地区では、「住宅再建支援制度」50.0\%、「ビニールシートの配布」 46. 4\%、「弁当の支給」 $41.1 \%$ であ(表 17)。

以上のことより、10 年を経過した後であっても、住宅復興補助 金の導入は必要であったことがわかった。その理由として、現実 的な資金援助の必要性に加えて、住夕続けるためや人口流出を防 ぐための必要性を挙げていることは特徴的である。また決定時期 は、早期決断(震災後 17 日目)により、被災者を元気づけるだけで なく、心の支えや安心感にもつながっていくことがわかった。そ のため満足度は、いずれの地区でも「満足」「やや満足」とあわ せて 6 割程度とかなり高い注7)。しかし一方で課題としては、「被

表5 被災者向け住宅復興事業補助金 ${ }^{25)}$

\begin{tabular}{|c|c|c|c|c|c|c|}
\hline \multirow{2}{*}{\begin{tabular}{|l|} 
\\
市町村名 \\
\end{tabular}} & & \multicolumn{2}{|c|}{ 2003年度最終実績 $(2004.3 .30)$} & \multirow{2}{*}{\begin{tabular}{c|} 
単位：千円 \\
液状化建物復旧
\end{tabular}} & \multicolumn{2}{|c|}{ ) 内の数字は割合を示す } \\
\hline & & 住宅建設 & 住宅補修 & & 石垣補修 & 計 \\
\hline \multirow{4}{*}{ 日野町 } & 県費 & 204,000 & 520,647 & 0 & 137,429 & 862,076 \\
\hline & 市町材费 & 102,000 & 795,248 & 0 & 274,857 & $1,172,105$ \\
\hline & 計 & 306,000 & $1,315,895$ & 0 & 412,286 & $2,034,181$ \\
\hline & 件数 & 102 & 1,287 & 0 & 415 & 1,804 \\
\hline \multirow{4}{*}{$\begin{array}{l}\text { 鳥取県 } \\
\text { 全体 } \\
\text { 合 }\end{array}$} & 県費. & $1,039,727$ & $4,097,827$ & 131,019 & 332,718 & $5,601,291$ \\
\hline & 夺町村費 & 519,364 & $3,361,850$ & 129,395 & 478,614 & $4,489,223$ \\
\hline & $\begin{array}{ll}\text { 計 } \\
\end{array}$ & $1,559,091$ & $7,459,677$ & 260,414 & 811,332 & $10,090,514$ \\
\hline & 件数 & 520 & 11,933 & 259 & 1,124 & 13,836 \\
\hline
\end{tabular}

表6 日野町の被災直後 (2001年) と2015年の家屋状況の変化注6)

\begin{tabular}{|c|c|c|c|c|c|c|c|c|c|c|c|c|c|c|c|c|c|c|c|c|c|}
\hline \multirow{4}{*}{ 対象地区 } & \multicolumn{21}{|c|}{ 罹災判定 } \\
\hline & \multicolumn{6}{|c|}{ 全壊 } & \multicolumn{6}{|c|}{ 半壊 } & \multicolumn{6}{|c|}{ 一部破損 } & \multicolumn{3}{|c|}{ 罹災判定なし } \\
\hline & \multirow[b]{2}{*}{ 現存 } & \multicolumn{2}{|c|}{ 2000年 2010年 } & \multicolumn{2}{|c|}{ 2010年 2015年 } & \multirow[b]{2}{*}{ 合計 } & \multirow[b]{2}{*}{ 現存 } & \multicolumn{2}{|c|}{ 2000年 2010年 } & \multicolumn{2}{|c|}{ 2010年～2015年 } & \multirow[b]{2}{*}{ 合計 } & \multirow[b]{2}{*}{ 現存 } & \multicolumn{2}{|c|}{ 2000年 2010年 } & \multicolumn{2}{|c|}{ 2010年 2015年 } & \multirow[b]{2}{*}{ 合計 } & \multicolumn{2}{|c|}{ 2000年 2010年 } & \multirow[b]{2}{*}{ 合計 } \\
\hline & & $\begin{array}{c}\mathrm{A} \\
\text { (建直L) }\end{array}$ & $\begin{array}{c}\mathrm{B} \\
\text { (空地) }\end{array}$ & $\begin{array}{c}\mathrm{A} \\
\text { (建直L) }\end{array}$ & $\begin{array}{c}\mathrm{B} \\
\text { (空地) }\end{array}$ & & & \begin{tabular}{c|}
$A$ \\
(建直L)
\end{tabular} & $\begin{array}{c}\mathrm{B} \\
\text { (空地) }\end{array}$ & $\begin{array}{c}\text { A } \\
\text { (建直L) }\end{array}$ & $\begin{array}{c}\mathrm{B} \\
\text { (空地) }\end{array}$ & & & $\begin{array}{c}A \\
\text { (建直L) }\end{array}$ & $\begin{array}{c}\mathrm{B} \\
\text { (空地) }\end{array}$ & $\begin{array}{c}\mathrm{A} \\
\text { (建直L) }\end{array}$ & $\begin{array}{c}\mathrm{B} \\
\text { (空地) }\end{array}$ & & $\begin{array}{c}\mathrm{A} \\
\text { (建直L) }\end{array}$ & $\begin{array}{c}\mathrm{B} \\
\text { (空地) }\end{array}$ & \\
\hline S地区 & 7 & 6 & 0 & 0 & 0 & 13 & 64 & 3 & 3 & 1 & 0 & 71 & 1 & 0 & 0 & 0 & 0 & 1 & 1 & 0 & 1 \\
\hline N地区 & 5 & 5 & 1 & 0 & 0 & 11 & 49 & 3 & 3 & 0 & 0 & 55 & 183 & 13 & 7 & 0 & 0 & 203 & 2 & 0 & 2 \\
\hline K地区 & 16 & 16 & 2 & 0 & 0 & 34 & 69 & 9 & 1 & 2 & 0 & 81 & 80 & 4 & 1 & 0 & 0 & 85 & 3 & 1 & 4 \\
\hline
\end{tabular}


表7 日野町の被災直後 (2001年) と2015年の人口・世帯状況の変化注6)

() 内の数值は、人口においては外国人数、世帯数においては外国人単独世帯数

\begin{tabular}{|c|c|c|c|c|c|c|c|c|c|c|c|c|}
\hline & \multicolumn{4}{|c|}{ 2000年(平成12年4月1日) } & \multicolumn{4}{|c|}{ 2010年(平成22年4月1日) } & \multicolumn{4}{|c|}{ 2015年(平成27年4月1日) } \\
\hline & \multicolumn{3}{|c|}{ 人 口 } & \multirow{2}{*}{ 世帯数 } & \multicolumn{3}{|c|}{ 人 口 } & \multirow{2}{*}{ 世帯数 } & \multicolumn{3}{|c|}{ 人 口 } & \multirow{2}{*}{ 世帯数 } \\
\hline & 男 & 女 & 総数 & & 男 & 女 & 総数 & & 男 & 女 & 総数 & \\
\hline S地区 & 186 & 208(1) & $394(1)$ & 134 & 164 & $181(2)$ & $345(2)$ & 133 & 146 & $157(2)$ & $303(2)$ & 130 \\
\hline N地区 & 395 & $493(1)$ & $888(1)$ & $336(1)$ & 324 & 418 & 742 & 333 & 288 & 383(1) & 671(1) & $328(1)$ \\
\hline K地区 & 335 & $389(4)$ & $724(4)$ & 261(1) & 255 & $304(4)$ & $559(4)$ & $242(2)$ & 232 & $276(8)$ & $508(8)$ & $226(6)$ \\
\hline
\end{tabular}
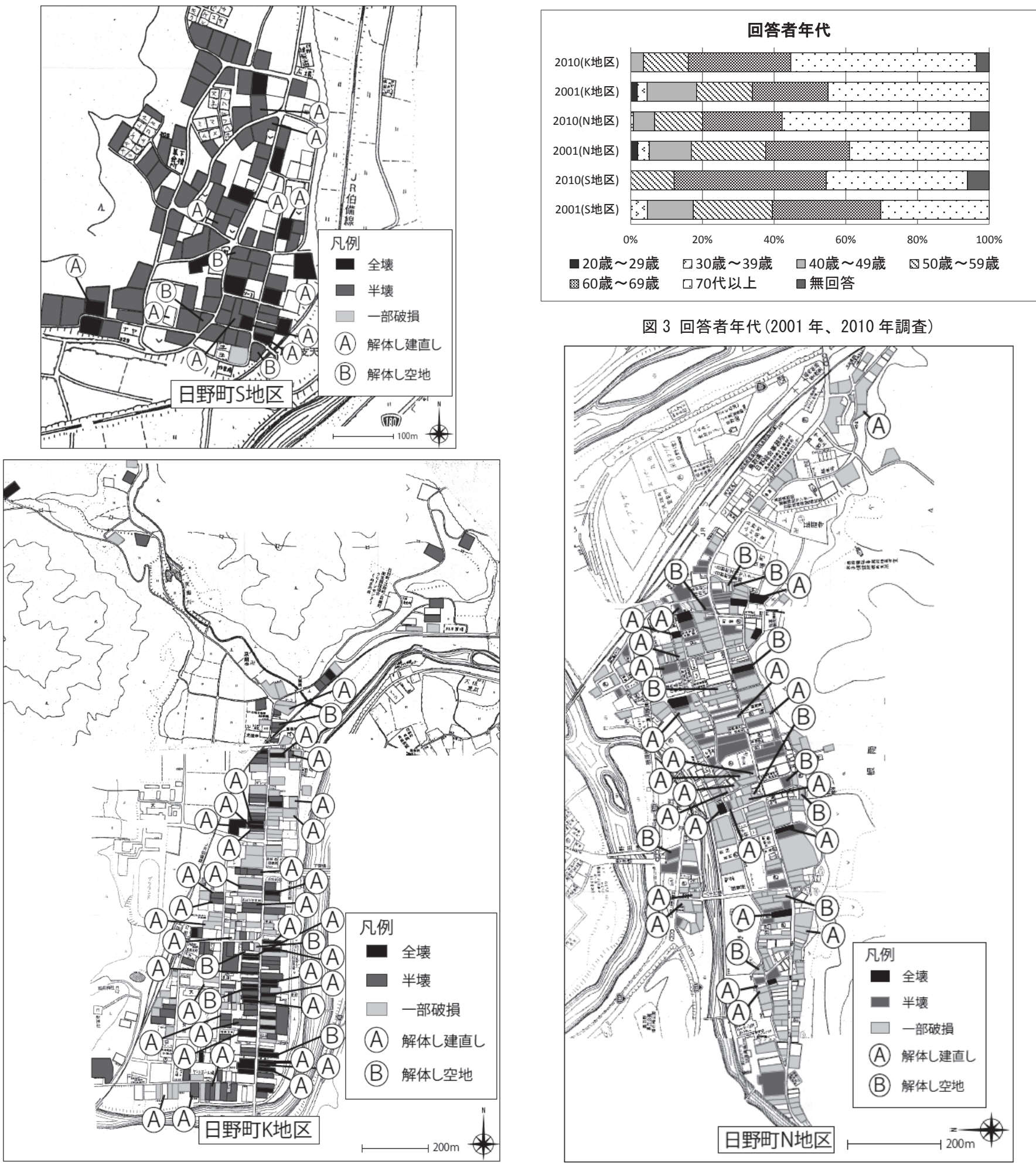

図 3 回答者年代 (2001 年、2010 年調査)

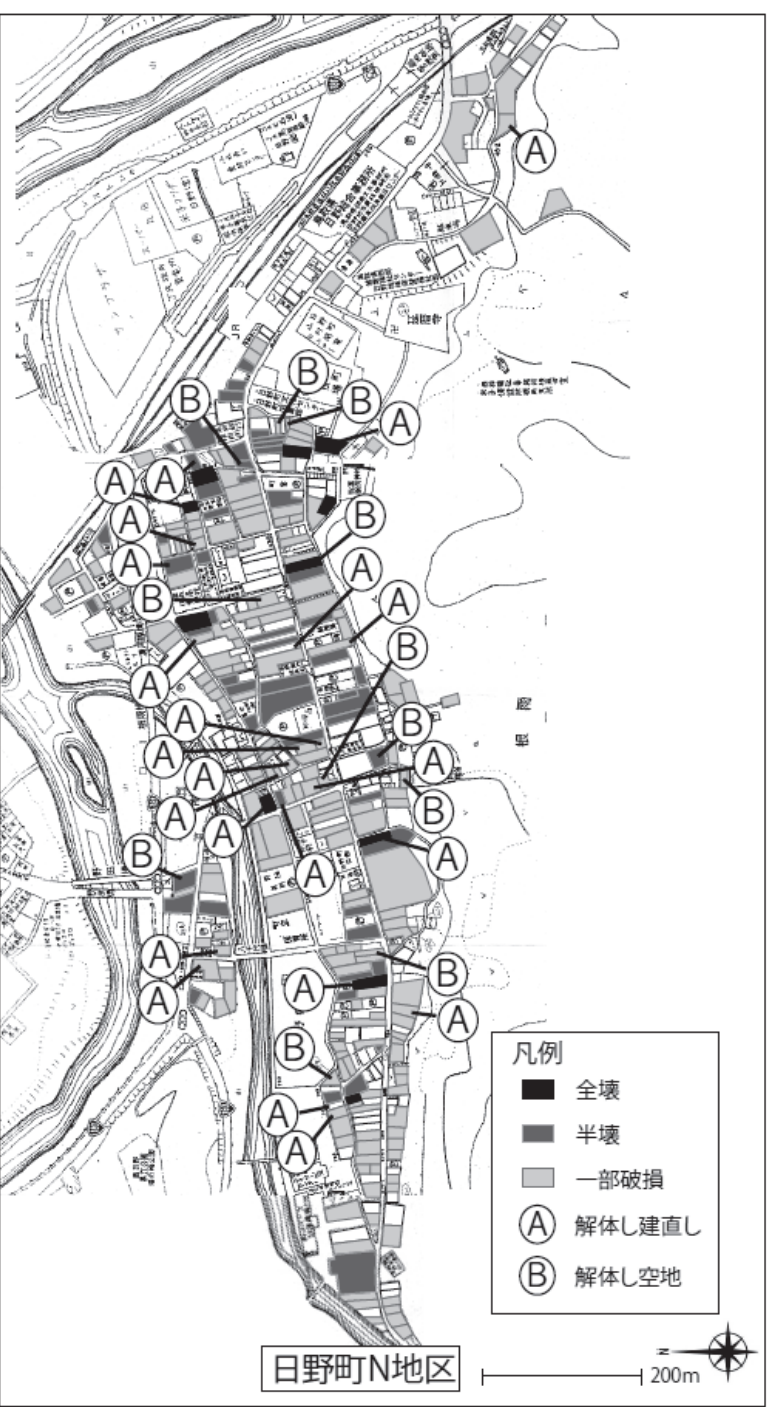

図 2 被災直後 $(2001$ 年) と 2015 年の家屋状況の変化注 6) 


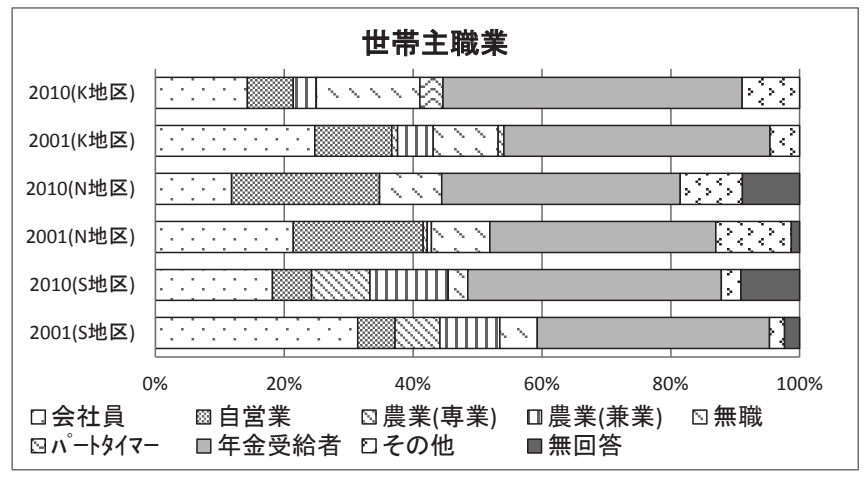

図 4 世帯主職業 (2001 年、2010 年調査)

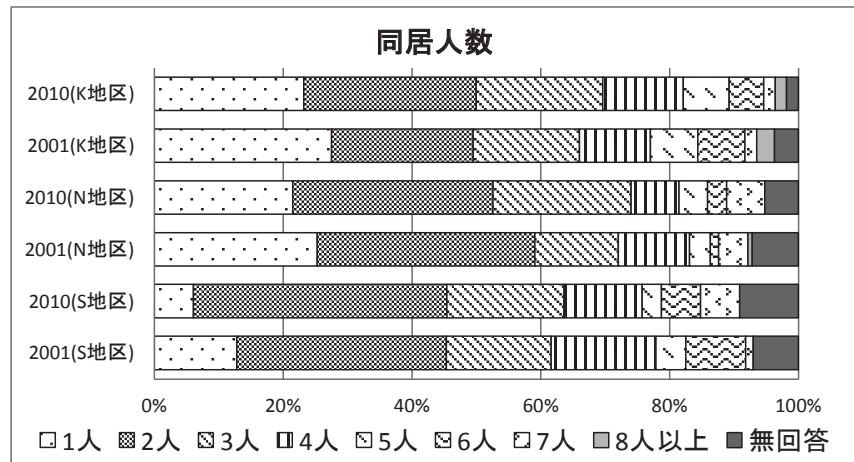

図 5 同居人数 (2001 年、2010 年調査)

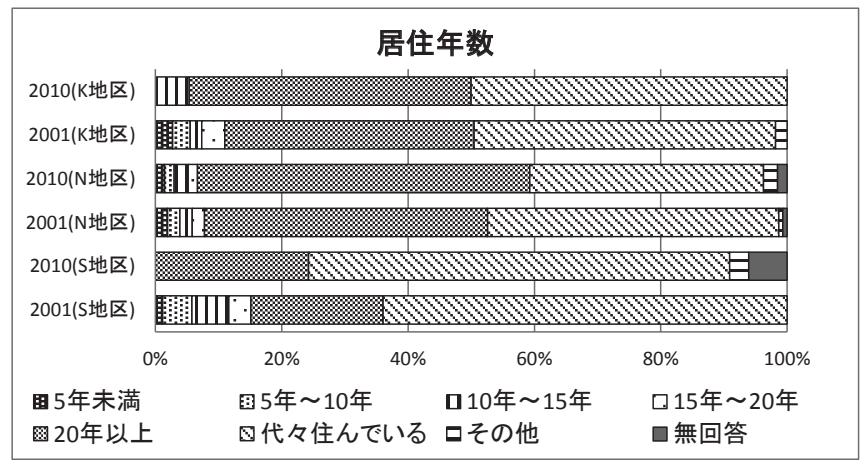

図 6 居住年数 (2001 年、2010 年調査)

表 8 生活への影響 (2001 年調査)

\begin{tabular}{|c|c|c|c|c|c|c|}
\hline \multirow{2}{*}{ 生活への影響 } & \multicolumn{2}{|c|}{ S地区 } & \multicolumn{2}{|c|}{ N地区 } & \multicolumn{2}{|c|}{ K地区 } \\
\hline & 人数 & 比率(\% & 人数 & 比率(\%) & 人数 & 比率(\% \\
\hline $\begin{array}{l}\text { 農業用ため池や水路が壊れ、転作や休耕を } \\
\text { 溞いられ、家計が苦しい }\end{array}$ & 30 & 34.9 & 1 & 0.6 & 1 & 0.9 \\
\hline 経営している商店、会社が営業不振である & 3 & 3.5 & 15 & 9.7 & 4 & 3.7 \\
\hline 震災前より大幅に収入が減った & 12 & 14.0 & 12 & 7.8 & 7 & 6.4 \\
\hline 家を失い、ローンナジが残っている & 3 & 3.5 & 0 & 0 & 1 & 0.9 \\
\hline 仮住まいで、住みづらい思いをしている & 5 & 5.8 & 3 & 1.9 & 7 & 6.4 \\
\hline 親しかった近所の人達と離れてしまい寂しい & 3 & 3.5 & 2 & 1.3 & 8 & 7.3 \\
\hline 生活への影響はそれほどない & 25 & 29.1 & 107 & 69.5 & 70 & 64.2 \\
\hline その他(口ーン、修理賸、生活不安定、体調不良等) & 12 & 14.0 & 18 & 11.7 & 16 & 14.7 \\
\hline 無回答 & 13 & 15.1 & 11 & 7.1 & 7 & 6.4 \\
\hline
\end{tabular}

表 9 今後の予定 (2001 年調査)

\begin{tabular}{|l|r|r|r|r|r|r|}
\hline \multirow{2}{*}{ 今後の予定 } & \multicolumn{2}{|c|}{ S地区 } & \multicolumn{2}{c|}{ N地区 } & \multicolumn{2}{|c|}{ K地区 } \\
\cline { 2 - 8 } & 人数 & 比率(\%) & 人数 & 比率(\%) & 人数 & 比率(\%) \\
\hline 住み続けたたい & 77 & 89.5 & 113 & 73.4 & 87 & 79.8 \\
\hline 出来れば住み続けナたい & 6 & 7.0 & 23 & 14.9 & 15 & 13.8 \\
\hline 迷っている & 1 & 1.2 & 7 & 4.5 & 4 & 3.7 \\
\hline 出来れば移りたい & 0 & 0 & 1 & 0.6 & 0 & 0 \\
\hline 移る予定である & 1 & 1.2 & 6 & 3.9 & 0 & 0 \\
\hline その他 & 0 & 0 & 3 & 1.9 & 2 & 1.8 \\
\hline 無回答 & 1 & 1.2 & 1 & 0.6 & 1.9 & 0.9 \\
\hline
\end{tabular}

表 10 定住理由 (2001 年調査)

\begin{tabular}{|l|r|c|r|r|r|r|}
\hline \multirow{2}{*}{ 定住理由 } & \multicolumn{2}{|c|}{ S地区 } & \multicolumn{2}{|c|}{ N地区 } & \multicolumn{2}{|c|}{ K地区 } \\
\cline { 2 - 7 } & 人数 & 比率(\%) & 人数比率(\%) & 人数 & 比率(\%) \\
\hline 親の代から住んでいる & 55 & 64.0 & 82 & 53.2 & 62 & 56.9 \\
\hline 近くに知人、友人がいる & 15 & 17.4 & 49 & 31.8 & 35 & 32.1 \\
\hline 困った時に助けてくれる人がいる & 6 & 7.0 & 19 & 12.3 & 15 & 13.8 \\
\hline 通勤、仕事が便利 & 10 & 11.6 & 16 & 10.4 & 10 & 9.2 \\
\hline 新鮮な農作物が食べられない & 4 & 4.7 & 2 & 1.3 & 2 & 1.8 \\
\hline 家貸、土地代が安い & 3 & 3.5 & 4 & 2.6 & 3 & 2.8 \\
\hline 余震が怖い & 0 & 0 & 0 & 0 & 3 & 2.8 \\
\hline 地震をれたい忘れ & 0 & 0 & 1 & 0.6 & 0 & 0 \\
\hline 新しい住宅に入った & 0 & 0 & 0 & 0 & 2 & 1.8 \\
\hline 公的資金の援助が得られた & 5 & 5.8 & 9 & 5.8 & 6 & 5.5 \\
\hline その他 & 3 & 3.5 & 21 & 13.6 & 9 & 8.3 \\
\hline 無回答 & 6 & 7.0 & 3 & 1.9 & 1 & 0.9 \\
\hline
\end{tabular}

表 11 被災住宅の再建方法 (2001 年調査)

\begin{tabular}{|l|r|r|r|r|r|r|}
\hline \multirow{2}{*}{ 被災住宅の再建方法 } & \multicolumn{2}{|c|}{ S地区 } & \multicolumn{2}{c|}{ N地区 } & \multicolumn{2}{|c|}{ K地区 } \\
\cline { 2 - 8 } & 人数 & 比率(\%) & 人数 & 比率(\%) & 人数 & 比率(\%) \\
\hline 現在のまま住む & 15 & 18.1 & 39 & 27.9 & 23 & 22.1 \\
\hline 補修、補強して住む & 58 & 69.9 & 91 & 65.0 & 72 & 69.2 \\
\hline 本格的に建て直す & 5 & 6.0 & 4 & 2.9 & 8 & 7.7 \\
\hline 急的に建て直す & 0 & 0 & 1 & 0.7 & 0 & 0 \\
\hline 地区内で戸建(中古物件含む)を買う & 0 & 0 & 0 & 0 & 0 & 0 \\
\hline 地区内で戸建てを借りる & 0 & 0 & 0 & 0 & 0 & 0 \\
\hline その他 & 1 & 1.2 & 5 & 3.6 & 1 & 1.0 \\
\hline 無回答 & 4 & 4.8 & 0 & 0 & 0 & 0 \\
\hline
\end{tabular}

表 12 公的支援の必要性 (2010 年調査)

\begin{tabular}{|l|r|r|r|r|r|r|}
\hline \multirow{2}{*}{ 公的支援の必要性 } & \multicolumn{2}{|c|}{ S地区 } & \multicolumn{2}{|c|}{ N地区 } & \multicolumn{2}{|c|}{ K地区 } \\
\cline { 2 - 7 } & \multicolumn{1}{|c|}{ 人数 } & 比率(\%) & \multicolumn{1}{c|}{ 人数 } & 比率(\%) & \multicolumn{1}{c|}{ 人数 } & 比率(\%) \\
\hline 必要だった & 31 & 93.9 & 91 & 67.4 & 41 & 73.2 \\
\hline やや必要だった & 1 & 3.0 & 21 & 15.6 & 7 & 12.5 \\
\hline どちらとも言えない & 1 & 3.0 & 9 & 6.7 & 3 & 5.4 \\
\hline あまり必要ではなかっ & 0 & 0 & 5 & 3.7 & 1 & 1.8 \\
\hline 必要ではなかった & 0 & 0 & 2 & 1.5 & 1 & 1.8 \\
\hline その他 & 0 & 0 & 0 & 0 & 0 & 0 \\
\hline 無回答 & 0 & 0 & 7 & 5.2 & 3 & 5.4 \\
\hline
\end{tabular}

表 13 公的支援の決定時期 (2010 年調査)

\begin{tabular}{|c|c|c|c|c|c|c|}
\hline \multirow{2}{*}{ 公的支援の決定時期 } & \multicolumn{2}{|c|}{ S地区 } & \multicolumn{2}{|c|}{ N地区 } & \multicolumn{2}{|c|}{ K地区 } \\
\hline & 人数 & 比率(\%) & 人数 & 比率 $(\%)$ & 人数 & 比率(\% \\
\hline 早すぎた & 0 & 0 & 1 & 0.7 & 0 & 0 \\
\hline やや早すぎた & 3 & 9.1 & 3 & 2.2 & 1 & 1.8 \\
\hline 適当だった & 27 & 81.8 & 115 & 85.2 & 48 & 85.7 \\
\hline やや遅すぎた & 1 & 3.0 & 1 & 0.7 & 3 & 5.4 \\
\hline 遅すぎた & 0 & 0 & 0 & 0 & 0 & 0 \\
\hline その他 & 1 & 3.0 & 3 & 2.2 & 1 & 1.8 \\
\hline 無回答 & 1 & 3.0 & 12 & 8.9 & 3 & 5.4 \\
\hline
\end{tabular}

表 14 公的支援の支給基準 (2010 年調査)

\begin{tabular}{|l|r|r|r|r|r|r|}
\hline \multirow{2}{*}{ 公的支援の支給基準 } & \multicolumn{2}{|c|}{ S地区 } & \multicolumn{2}{|c|}{$\mathrm{N}$ 地区 } & \multicolumn{2}{|c|}{ K地区 } \\
\cline { 2 - 8 } & \multicolumn{1}{|c|}{ 人数 } & 比率(\%) & \multicolumn{1}{c|}{ 人数 } & 比率(\%) & 人数 & 比率(\%) \\
\hline 適正だった & 8 & 24.2 & 50 & 37.0 & 19 & 33.9 \\
\hline やや適正だった & 6 & 18.2 & 19 & 14.1 & 14 & 25.0 \\
\hline どちらとも言えない & 12 & 36.4 & 40 & 29.6 & 8 & 14.3 \\
\hline あまり適正でなかっ & 0 & 0 & 7 & 5.2 & 4 & 7.1 \\
\hline 適正ではなかった & 3 & 9.1 & 0 & 0 & 1 & 1.8 \\
\hline その他 & 1 & 3.0 & 6 & 4.4 & 4 & 7.1 \\
\hline 無回答 & 3 & 9.1 & 13 & 9.6 & 6 & 10.7 \\
\hline
\end{tabular}

表 15 公的支援の満足度 (2010 年調査)

\begin{tabular}{|l|r|r|r|r|r|r|}
\hline \multirow{2}{*}{ 公的支援の満足度 } & \multicolumn{2}{|c|}{ S地区 } & \multicolumn{2}{|c|}{ N地区 } & \multicolumn{2}{|c|}{ K地区 } \\
\cline { 2 - 8 } & \multicolumn{1}{|c|}{ 人数 } & 比率(\%) & \multicolumn{1}{|c|}{ 人数 } & 比率(\%) & 人数 & 比率(\%) \\
\hline 満足 & 10 & 30.3 & 51 & 37.8 & 24 & 42.9 \\
\hline やや満足 & 8 & 24.2 & 31 & 23.0 & 17 & 30.4 \\
\hline どちらとも言えない & 9 & 27.3 & 36 & 26.7 & 6 & 10.7 \\
\hline やや不満 & 3 & 9.1 & 3 & 2.2 & 3 & 5.4 \\
\hline 不満 & 1 & 3.0 & 1 & 0.7 & 1 & 1.8 \\
\hline その他 & 0 & 0 & 2 & 1.5 & 1 & 1.8 \\
\hline 無回答 & 2 & 6.1 & 11 & 8.1 & 4 & 7.1 \\
\hline
\end{tabular}


表 16 公的支援の課題 (2010 年調査)

\begin{tabular}{|l|r|r|r|r|r|r|}
\hline \multirow{2}{*}{ 公的支援の課題 } & \multicolumn{2}{|c|}{ S地区 } & \multicolumn{2}{|c|}{ N地区 } & \multicolumn{2}{|c|}{ K地区 } \\
\cline { 2 - 7 } & \multicolumn{1}{|c|}{ 人数 } & 比率 $(\%)$ & \multicolumn{1}{c|}{ 人数 } & 比率(\%) & 人数 & 比率 $(\%)$ \\
\hline 被災判定の基準 & 16 & 48.5 & 40 & 29.6 & 18 & 32.1 \\
\hline 支給判定の時期 & 1 & 3.0 & 9 & 6.7 & 3 & 5.4 \\
\hline 支給額 & 4 & 12.1 & 11 & 8.1 & 6 & 10.7 \\
\hline 内容のわかりにくさ & 1 & 3.0 & 13 & 9.6 & 6 & 10.7 \\
\hline 情報提供の方法 & 2 & 6.1 & 10 & 7.4 & 1 & 1.8 \\
\hline 書類作成の煩雑さ & 1 & 3.0 & 10 & 7.4 & 5 & 8.9 \\
\hline その他 & 3 & 9.1 & 10 & 7.4 & 6 & 10.7 \\
\hline 無回答 & 7 & 21.2 & 50 & 37.0 & 12 & 21.4 \\
\hline
\end{tabular}

表 17 有効な生活支援策 (2010 年調査)

\begin{tabular}{|c|c|c|c|c|c|c|}
\hline \multirow{2}{*}{ 有効な生活支援策 } & \multicolumn{2}{|c|}{ S地区 } & \multicolumn{2}{|c|}{ N地区 } & \multicolumn{2}{|c|}{ K地区 } \\
\hline & 人数 & 比率 $(\%)$ & 人数 & 比率(\%) & 人数 & 比率 $(\%)$ \\
\hline 炊き出し & 8 & 24.2 & 10 & 7.4 & 15 & 26.8 \\
\hline 弁当の支給 & 18 & 54.5 & 23 & 17.0 & 23 & 41.1 \\
\hline 給水 & 26 & 78.8 & 10 & 7.4 & 9 & 16.1 \\
\hline ビニールシートの配布 & 23 & 69.7 & 58 & 43.0 & 26 & 46.4 \\
\hline ボランティアの派遣 & 16 & 48.5 & 22 & 16.3 & 17 & 30.4 \\
\hline メンタルケアの実施 & 1 & 3.0 & 6 & 4.4 & 3 & 5.4 \\
\hline 義援金の支給 & 9 & 27.3 & 27 & 20.0 & 13 & 23.2 \\
\hline 応急危険度判定の実施 & 2 & 6.1 & 19 & 14.1 & 7 & 12.5 \\
\hline 罹災証明書の発行 & 12 & 36.4 & 41 & 30.4 & 17 & 30.4 \\
\hline 住宅再建支援制度 & 22 & 66.7 & 53 & 39.3 & 28 & 50.0 \\
\hline 生活再建支援制度 & 5 & 15.2 & 8 & 5.9 & 5 & 8.9 \\
\hline 住宅解体助成制度 & 11 & 33.3 & 13 & 9.6 & 11 & 19.6 \\
\hline その他 & 2 & 6.1 & 3 & 2.2 & 2 & 3.6 \\
\hline \begin{tabular}{|l} 
無回答 \\
\end{tabular} & 0 & 0 & 14 & 10.4 & 2 & 3.6 \\
\hline
\end{tabular}

災判定の基準」を挙げていて、被災者の被災判定基準への理解が進 んでいないことがわかった。有効な生活支援策は、「ビニールシー 卜の配布」「弁当の支給」「給水」等の物的な支援と「住宅再建支 援制度」等、国と地方自治体の法制度の整備の両方が必要であるこ とがわかった ${ }^{26)}$ 。

そこで、公的支援がどのような被災者に有効であったのかを明ら かにするために、罹災判定結果と満足度とのクロス集計を行い、そ の結果を述べる。被害状況は、国の支援から外れる半壊世帯や一部 破損世帯が多かったため、その支援件数は、住宅補修が 9 割近くを
占めた。このような状況を踏まえて、クロス集計結果をみてみると、 半壊や一部破損においても満足度は高い。被災者からの個別の回答 によれば、公的支援の意味として、現実的な資金援助だけでなく、 被災者の精神的支えとなったのではないかと推測される(図 7)。

\section{8. 鳥取県西部地域の震災前後の人口変動}

鳥取県西部地域の 2000 年と 2002 年の人口・世帯数を比べると、 2000 年 249,555 人 $\cdot 88,079$ 世帯、 2002 年 249,728 人 $\cdot 90,091$ 世帯 で、人口・世帯数とも微増している。さらに市町村別にみると、自 然減とみなせる町はあるが、人口が急減した市町村はない。被害が 甚大であった日野町の人口と世帯数の推移を 2000 年から 2015 年ま でみてみると、自然減はあるものの人口が急減していない27)（表 18） また国勢調查によれば、1990 年 5,377 人、1995 年 4, 921 人で、2000 年以降の人口推移とほとんど変わらない ${ }^{28)}$ 。したがって被災者の人 口・世帯流出は防ぐことができたと考える。鳥取県が導入した「住 宅再建」優先の制度は、中山間地域の住民にとって、迅速な決定で あったことや緊急支援としての意義があった。そして他の地域への 人口流出を抑えて、地域住民の自力再建への一助となった(図 7)。

\section{9. まとめ}

地震対策には、公助、共助、自助が大切である。公助については 行政による支援、共助についてはコミュニティで助け合う、自助に ついては自分で自分を助けることである。今回は中山間地域であり コミュニティの強い地域を対象にしており、住宅再建支援には特に、 行政による支援（公助）と住民みずからが自立して再建しようとす る意識（自助）があいまって初めて可能と考えている。そこで、は じめに住宅再建支援に対する行政の対応、次に公的支援に対する意 識を含めた各地域の住民意識の順にまとめを構成している。

（1）1998 年に制定された「支援法」は、初めて全壊や居住不可能者 の世帯に 100 万円を上限に現金支給を定めた。2000 年鳥取県西部地
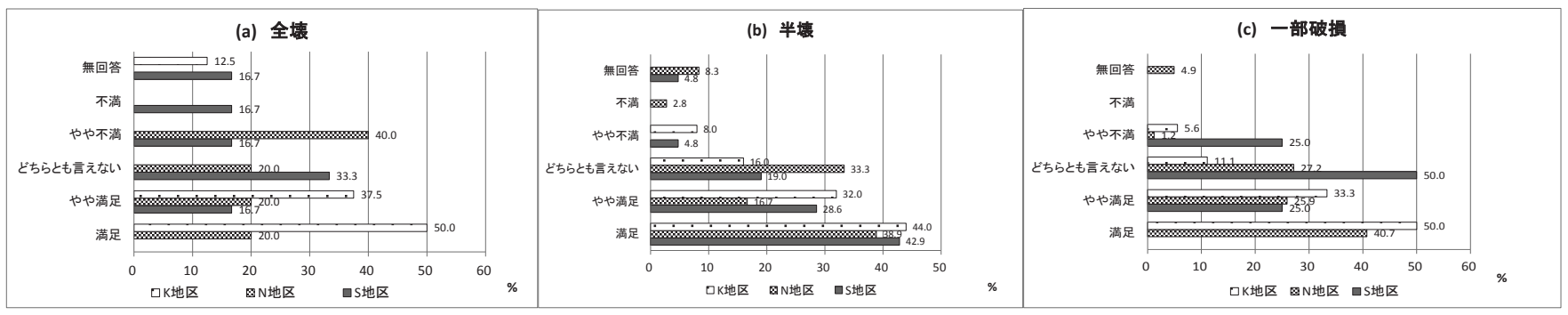

図7 罹災判定結果 $\times$ 満足度 (2010年調査)

表18 鳥取県日野町の震災後の人口・世帯数の推移 ${ }^{27)}$ (住民基本台帳をもとに、各年3月末日現在とする)

\begin{tabular}{|c|c|c|c|c|c|c|c|c|}
\hline \multirow{2}{*}{ 年次 } & \multirow{2}{*}{$\begin{array}{c}\text { 世帯数 } \\
\text { (戸) }\end{array}$} & \multicolumn{3}{|c|}{ 人口（人） } & \multirow{2}{*}{ 出生（人） } & \multirow{2}{*}{ 死亡（人） } & \multicolumn{2}{|c|}{ 転出入 (人) } \\
\hline & & 総数 & 男 & 女 & & & 転入 & 転出 \\
\hline 2000年 & 1,582 & 4,666 & 2,215 & 2,451 & 29 & 79 & 94 & 153 \\
\hline 2001年 & 1,558 & 4,539 & 2,141 & 2,398 & 23 & 58 & 125 & 217 \\
\hline 2002年 & 1,562 & 4,489 & 2,117 & 2,372 & 22 & 63 & 124 & 133 \\
\hline 2003年 & 1,567 & 4,490 & 2,122 & 2,368 & 31 & 50 & 174 & 154 \\
\hline 2004年 & 1,556 & 4,425 & 2,081 & 2,344 & 28 & 50 & 130 & 173 \\
\hline 2005年 & 1,543 & 4,327 & 2,028 & 2,299 & 26 & 57 & 85 & 152 \\
\hline 2010年 & 1,504 & 3,873 & 1,816 & 2,057 & 14 & 66 & 64 & 110 \\
\hline 2015年 & 1,431 & 3,466 & 1,590 & 1,876 & 11 & 56 & 99 & 110 \\
\hline
\end{tabular}


震は、制定当初の内容で運用された。2004 年新潟県中越地震は、法 改正が成され直後の地震で、「居住安定支援制度」の追加や、大規模 半壊世帯も支援対象となり拡充が図られた。その後 2007 年の法改正 は、住宅再建の形に応じて最大 300 万円を定額方式で支給し、使用 目的や支給対象の年齢及び年収要件を撤廃した。

(2) 地方自治体の補完制度としては、2000 年鳥取県西部地震で行っ た日本初の自治体独自の個人住宅への公的支援がある。全壊・半壊 の区別なく、住宅建築費に補助金の交付を行なうものであった。補 助金の執行状況からは、建替世帯よりもむしろ補修への対応が手厚 かったことが、他地域一の人口流出を抑えて、地域住民の自力再建 の支援に貢献した。しかし個人負担の大半を自治体で肩代りをした 日野町は、負担額が町財政を圧迫し、一時は財政破綻申請を検討す るに至った。

（3）地震後の住民意識調査では以下の通りである。半年後の調査 (2001 年)では、被災者の多くは地域に定着した住民のため、「住み 続けたい」等の意向が 9 割以上を占め、定住意識が高いことが読み 取れる。高齢者の多い地域では、住宅再建を希望する場合、建替え は困難であるため、そのような中での住宅復興補助金の導入は有効 的な施策であったが、多くの被苂者にとっては、将来への経済的不 安は大きく、土地を離れることなく住み続けることの難しさを浮き 彫りにしていた (表 11)。10 年後の調查 (2010 年)では、半年後の調 查同様に、被災者の多くは地域に定着した住民のため、「住夕続けた い等の意向が 9 割以上を占め、定住意識が高いことが読み取れる。 そしてほとんどの住宅に被害がみられるため、8 割以上が公的支援 を受けていることがわかる。公的支援について、公的支援そのもの は必要であり、その理由として、現実的な資金援助に加えて、住み 続けるためや人口流出を防ぐための必要性を挙げていて、ほぼ満足 のいくものであった。しかし課題をあげると「被災判定の基準」が いずれの地区でも突出する結果になった。このことは、当時は被災 判定が全壊・半壊・一部破損の 3 種類であったため、判定結果に納 得のいかない住民も多かった。そのため震災後に被災者相互のコミ ユニティに亀裂を生じた例もみられた。有効な生活支援策は、「ビ ニールシートの配布」「弁当の支給」「給水」等の物的な支援と「住 宅再建支援制度」等、国と地方自治体の法制度の整備の両方が必要 であることがわかった。鳥取県の対応の早さは評価されているが、 近隣の自治体 (市町村含) での対応の差が、被災者間の不公平さを生 じる要因となるため、統一的な支援策も必要であると考える。

(4) 地震直後の人口変動について、鳥取県西部地域の 2000 年と 2002 年の人口・世帯数を比べると、自然減はみられるものの、人口・世 帯数とも急減した市町村はない。被害が甚大であった日野町の人口 と世帯数の推移を 2000 年から 2015 年までみてみると、自然減はあ るものの人口が急減していない。

\section{0. 今後の課題}

(1) 鳥取県は、全国ではじめて住宅に公的支援制度を地震後すぐに導 入を決定した。液状化住宅もその後すぐに含まれ、迅速な決定であ ったことや緊急支援としての意義があった。地域の維持・再生につ いて、公的支援により住民の定住意識の持続、人口・世帯数の維持、 住宅再建はなされたが、住宅再建の際、地域の固有の文化を育む住 まいとしての住宅建設が行なわれているとは言い難い。したがって、
住宅再建のための公的支援が、個々の再建に留まらず、地域の固有 の文化の維持と継承に貢献するように、補修や建設の方法等を含め たまちづくり計画に則った復興計画を検討する必要があると考える。 (2) 2007 年の改正で、住宅再建への補助を認めたことや、支給対象 の年齢や年収要件撤廃など改善は成されたが、半壊世帯は対象外と された。今後は対象外世帯に対して補助金だけでなく、これまで以 上に助成金制度の拡充を行っていくことや、地域の維持再生を念頭 にまちづくりと住宅再建とを連動させた地域連携型のシステムづく り ${ }^{29}$ 等、多様な支援策の方向性を示唆する必要があるといえる。住 民にとって被災判定基準の明確さや申請手続きの簡素化と分かりや すさについては、今後も議論される余地が残されたままである。

\section{謝辞}

調查にあたり日野町の被災者の方々、鳥取県・島根県・鳥取県西 部広域行政管理組合・日野町をはじめ鳥取県内各市町村の担当職員 の方々に、ご協力頂きましたこと厚く御礼を申し上げます。

\section{注}

注 1) 2001 年と 2010 年の両調查は、全世帯調査を行っている。また 10 年間に おいて人口の自然増減はみられるが、回答者の居住年数から判断して、 2010 年の調查対象者は、 10 年前の 2001 年の被災者であると考えている。

注 2) 鳥取県は、本州西端に位置する中国地方の北東部に位置する東西にやや 細長い県である。総面積 3, 507. 25 平方 $\mathrm{km}(2004.10 .1)$ 、人口 582,618 人 (2012.6.1 推計)、世帯数 213,832 世帯 (2012.6.1 推計)、市町村数は 4 市 14 町 1 村 の計 19 市町村（2006.4）である。なお本論文で使用する 市町村名は、震災当時のものとする。

注 3) 日野町は、鳥取県西南部に位置し、東西 $20 \mathrm{~km}$ 、南北 $12.5 \mathrm{~km}$ 、総面積 $133.98 \mathrm{~km}$ で、岡山県、江府町、伯耆町、日南町に接している。日野町は、 人口 3,352 人、世帯数 1,412 世帯 (2016.9.1 推計)で、中山間部に属す る町のひとつで、農林業を中心とする第一次産業の衰退や、出産率の低 下による若年層を中心とする人口減少と高齢化が進んでいる町である。

注4) 兵庫県が地震等の自然災害で被災した住宅の再建を目的に、2005年9月か ら運用を始めた独自の制度として、「住宅再建共済制度」がある。兵庫県 被災者住宅再建支援制度調査会 (座長 : 室崎益輝) がまとめた「兵庫県被 災者住宅再建支援制度 (仮称) 創設に係る最終報告書」は、自然災害によ って半壞以上の被害がある場合、住宅の再建・購入・新築に600万円、住 宅の補修に、全壊の場合 200 万円・大規模半壊の場合 100 万円・半壊の場 合50万円、再建や補修を行なわない場合は 10 万円を給付する等というも のである。そして住宅 1 戸当たり年間 5000 円の定額掛け金で、加入方法 は任意加入で兵庫県独自の事業として事務手続きの簡素化も図ろうとし ている。台風 9 号災害に伴い、平成 21 年度に制度創設以降初めて共济給 付金の給付を行った。

http://web. pref. hyogo. jp/wd34/documents/000013570. pdf

注 5) 2004 年に台風等の自然災害で「支援法」が適用された 13 府県 (新潟県・

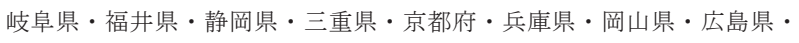
徳島県・ 香川県 $\cdot$ 愛媛県・佐賀県) のうち、9 府県 ( 新潟県・岐阜県・福 井県・三重県・京都府・兵庫県・広島県・徳島県・愛媛県) が独自の再建 支援策を実施した。そのうち 7 府県 (新潟県・岐阜県・福井県・三重県・ 京都府・兵庫県・徳島県) が建築費を支援対象に盛り込んでいる。福井県・ 京都府・徳島県の 3 府県では、世带収入などによる支給制限も撒廃して 適用を拡大寸る等、「支援法」の制度を補完する自治体が相次いだ。

注6)この資料は、鳥取県日野町役場からの資料提供によるまとめで、被災直 後 (2001年) は、2001年3月5日付「鳥取県西部地震災害調查資料」、2015 年は、「日野町固定資産台帳（日野町土地家屋償却資産課税台帳）」 2015 年1月1日現在のものである。

注7)筆者らは、液状化被害が顕著な米子市でのアンケート調查を実施してい る。公的支援の満足度は6割強で、日野町調查と同様な結果を示している 30)。

参考文献

1) 浅井秀子・熊谷昌彦・樋口秀: 中山間地域の地震災害における住宅再建支援 
策の課題－2000 年鳥取県西部地震と 2004 年新潟県中越地震の事例一,

日本建築学会技術報告集，第 16 巻，第 32 号，pp. 405-410，2010． 2

2) 重川希志依・田中聡・高島正典：才まいの再建支援策相互の連関と課題の分 析一新潟県中越地震における小千谷市の事例一, 地域安全学会論文集, No8, pp 1-10, 2006. 11

3) 阿部泰隆：大震災被災者への個人補償 政策法学からの吟味，ジュリスト, 1070, pp 135-142, 1995

4) 浦部法穂：被災者に対する「公的支援」と憲法，自由と正義，1997８８

5) 福崎博孝：地震・噴火・津波災害に対する国民的保障制度，自由と正義， 1997. 8

6) 田近栄治・佐藤主光：生活再建のための公的支援の課題とあり方，阪神・淡 路大震災5 周年記念事業震災対策国際総合検証報告会, 2000. 1

7) 被災者の住宅再建支援の在り方に関する検討委員会：被災者の住宅再建支 援の在り方に関する検討委員会報告書, 2000. 12,

http://www. bousai.go. jp/kohou/oshirase/h12/121204.html (参照 2004.3.4)

8) 佐藤主光：災害時の公的支援に対する経済学の視点, 会計検査研究, №.32, 2005. 9

9）大塚路子・小澤隆：被災者生活再建支援，調査と情報，第437号，2004．2. 4

10) 高田光雄：大震災における住宅被害の構造と復興の課題, 住宅災害の実 態と住宅復興プロセス, 日本建築学会, pp 7-18, 1995. 8

11) 室崎益輝：特集 地震はなぜ起きるのか災害復興の課題と方向，日本の科 学者, vol. 31, no. 12, 通巻347号, 日本科学者会議, pp 20-24, 1996. 12

12) 吉村美保・目黒公郎：兵庫県南部地震での住宅被災者に対する公助の実態 分析, 日本建築学会環境系論文集, No. 586, pp 99-106, 2004. 12

13) 木村玲欧・林春男 - 立木茂雄・浦田康幸：阪神・淡路大震災後の被苂者の移 動とすまいの決定に関する研究，地域安全学会梗概集，No. 1, pp 93-102, 1999. 11

14）木村玲欧・田村圭子・井ノ口宗成・林春男・浦田康幸：災害からの被災者行 動·生活再建過程の一般化の試み, 地域安全学会梗概集, No. $13, \mathrm{pp}$ 175-185, 2010. 11

15) 木村玲欧・林春男・立木茂雄・田村圭子：被災者の主観的時間評価からみた 生活再建過程, 地域安全学会梗概集, No. 6, pp 241-250, 2004. 11

16) 大西一嘉：鳥取県西部地震における住宅復興支援策の評価に関する研究, 地域安全学会論文集, No. 4, 2002. 11

17) 村上ひとみ・三樹亮介・林康裕・北原昭男：2000年鳥取県西部地震による被 災住宅の復旧に関する意志決定，地域安全学会梗概集，No. 12，pp 99-102， 2002. 11

18) 日本建築学会編：2000年鳥取県西部地震調査報告書2001年芸予地震調査 報告書, 日本建築学会, 2001. 10

19) 鳥取県: 平成 12 年鳥取県西部地震の記録, 2001. 10

20) 鳥取県：震災誌 平成12年 (2000年) 鳥取県西部地震, 2007。2

21) 浅井秀子.熊谷昌彦：鳥取県西部地震災害における生活再建への公的支援 の意味について, 日本建築学会地域施設計画研究 22, pp 73-78, 2004. 7

22) 浅井秀子.熊谷昌彦：鳥取県西部地震災害における生活再建への公的支援 の評価について, 日本建築学会地域施設計画研究 23, pp 417-424, 2005. 7

23) 北原昭男 - 林康裕·奥田辰雄・鈴木祥之·後藤正美：2000 年鳥取県西部地震 における木造建物の構造特性と被害, 日本建築学会構造系論文集, Vol. 67, No. 561, pp 161-167, 2002. 11

24) 熊谷昌彦.三吉優子・浅井秀子：鳥取県西部地震直後の初動と公的支援に ついて一鳥取県の事例一, 日本建築学会地域施設計画研究 21, pp 27-32, 2003. 7

25) 鳥取県住宅環境課：鳥取県西部地震住宅復興補助金申請件数，2002. 9 . 30

26) 重川希志依・田中聡・高島正典：被災者生活再建支援法改正過程の分析, 地 域安全学会論文集, No10, pp 253-260, 2008. 11

27）日野町総務課：鳥取県日野町の年次別人口・世帯数の推移，2015３３３1 28) 鳥取県: 国勢調査, 時系列データ (鳥取県), 男女別人口及び人口性比, 日 野町, http://www. pref. tottori.1g. jp/261310.htm(参照 2016.9. 16)

29) 熊谷昌彦・内田伸・樋口秀：能登半島地震における住民によるまちづくり の復興支援に関する調査研究, 日本建築学会中国支部研, 第32巻, 2009. 3

30) 浅井秀子：鳥取県西部地震における住宅の生活再建についての居住者意 識に関する研究一米子市安倍彦名団地の事例一, 鳥取短期大学研究紀要, 第50号，pp 111-119，2004. 12 


\title{
THE REALITY OF THE HOUSING RECONSTRUCTION SUPPORT 10 YEAR LATER OF 2000 WESTERN TOTTORI EARTHQUAKE AND THE PROBLEM JUDGED FROM RESIDENT CONSCIOUSNESS
}

\author{
Hideko ASAI* and Masahiko KUMAGAI**
}

\footnotetext{
* Assoc. Prof., Graduate School of Engineering, Tottori University, Dr. Eng.

** Prof., Dept. of Architecture, Yonago National College of Technology, Dr. Eng.
}

The problem to consider the overall victim of an accident support which is based on a case of western Tottori earthquake、 this research is having to do the excercise judged from the reality of the housing reconstruction support and resident's consciousness 10 years later.

Resident's endurance of the settlement consciousness、 population and number of households were maintained by doing housing reconstruction support. But it is difficult to say that housing as peculiar culture in an area was constructed. Therefore housing reconstruction support has to consider a rehabilitation plan including repairs and ways of construction、 to contribute to peculiar cultural maintenance and succession.

A change in a victim of an accident living reconstruction supporting method did the age of the supplied object and annual income important matter abolition、 and was improved in 2007. But it assumed that the partially-destroyed household was non-applicable.

Expansion of a grant system、 community building of maintenance revival in an area and systematization of the area cooperation type that made connected with housing reconstruction、 it'll be necessary to suggest various directionality as well as the subsidy to a non-applicable household from now on.

Clearness of the hit acceptance standard and implification of application procedure、 it'll be also necessary to be argued from now on. 